\section{Is the reductionist beyond belief?}

\section{William Paton}

God and the New Biology. By Arthur Peacocke. Dent: 1986. Pp.198. £10.95. To be published in the United States by Harper \& Row.

"THE brain secretes thought as the liver secretes bile; and you are all just bundles of conditioned reflexes". With this ending to his lectures on the alimentary tract, my physiology professor, the late John Mellanby, leant on his elbow on the lectern, and beamed at us. Although he seemed a pretty implausible reflex-bundle himself, that, 50 years ago, was my first introduction to reductionism. A.J. Ayer's Language, Truth and Logic was also giving logical positivism a brisk run. An advanced cleric of the day, L.W. Grensted, was said to believe that "There is no God, men are monkeys and there may be spooks". To the eye today, it was all good clean fun.

Faith, reductionism, the "enfant terrible" and the "advanced cleric" are still with us - but the antitheses are less sharp. The church has learnt to face the criticisms of rigorous scholarship, and science that

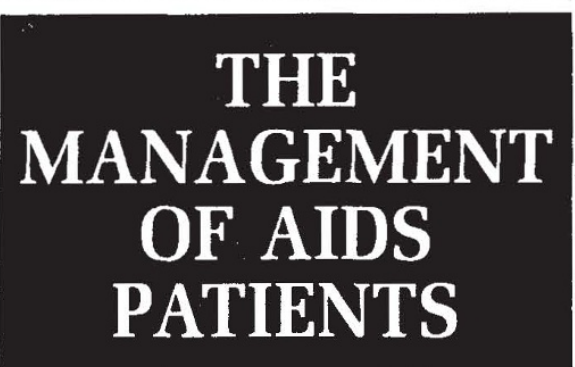

\begin{tabular}{|c|c|c|c|}
\hline \multirow{2}{*}{\multicolumn{4}{|c|}{$\begin{array}{l}\text { Edited by DAVID MILLER, } \\
\text { JONATHAN WEBER and JOHN GREEN } \\
\text { The Management of AIDS Patients is the } \\
\text { first comprehensive guide to the practical } \\
\text { clinical management of patients with AIDS } \\
\text { or HTLV III infections. The book avoids the } \\
\text { sensational aspects of the disease, offering } \\
\text { solid advice and information for all people } \\
\text { involved in patient care. }\end{array}$}} \\
\hline & & & \\
\hline \multicolumn{4}{|c|}{$\begin{array}{l}\text { The editors and many of the contributors } \\
\text { come from St Mary's Hospital, London one } \\
\text { of the foremost centres in Britain for the } \\
\text { treatment of AIDS patients. The knowledge } \\
\text { and experience of these experts has been } \\
\text { combined to provide a much-needed book } \\
\text { for doctors, nurses, dentists and indeed for } \\
\text { health-care professionals everywhere. }\end{array}$} \\
\hline \multicolumn{4}{|c|}{1986} \\
\hline $200 p p$ & Hardback & 0333404653 & $£ 30.00$ \\
\hline \multicolumn{4}{|c|}{$\begin{array}{l}\text { Please order this title from your bookseller - or in case of } \\
\text { difficulty from Judy Chappell, Macmillan Press, } \\
\text { Houndmills, Basingstoke. Hants RG21 2XS. }\end{array}$} \\
\hline & & I & \\
\hline
\end{tabular}

BOOK REVIEWS

the ethical problems it can create need ethical principle not of its making for their resolution. Leaders of science and religion are now less prone to pronounce at each other's expense.

Dr Peacocke's book on biological reductionism is admirably consonant with this atmosphere. He is well-qualified; a physical biochemist and tutor in Oxford, who took orders, became a college chaplain in Cambridge and is now director of the Ian Ramsey Centre in Oxford, an institution recently founded for the study of ethical problems in science and medicine. The book pulls together his thinking over a number of years.

His conclusion is best given in his own words (though they are more precise than colourful):

It is possible for higher level concepts and theories... to be non-reducible to lower level concepts and theories, that is, they can be autonomous. At the same time one has to recognise the applicability of the lower level concepts and theories (for example, those of physics and chemistry) to the component units of more complex entities and their validity when referred to that lower level. That is, with reference to biology, it is possible to be antireductionist without being a vitalist. Higher level concepts and theories often refer to genuine aspects of reality at their own level of operation and we have to eschew any assumptions that only the so-called fundamental particles of modern physics are "really real". To do so is indeed a kind of "fundamentalism" of a pseudo-scientific kind that is as much to be avoided in impartial enquiry as its religious namesake.

The book is a critical review of a rather extensive literature on and around the "reducing" implications of modern biology, molecular biology, genetics, evolution and sociobiology (but, deliberately, not neuroscience).

Dr Peacocke finds a genuine middle ground. The reductionist refuses to accept any "extra" (for example, entelechy or vital principle) beyond the laws of natural science in order to explain natural phenomena. The anti-reductionist finds it inconceivable that the full variety of biology and human life can be so explained without it. But molecular biology and genetics do bring one striking gift: the breadth of their explanatory power shows how, from simple elements, systems of astonishing complexity and richness can arise. Randomness presents itself not as some irrational intrusion, but as a source of creativity. And it seems that in these new systems, there is a kind of autonomy. Social behaviour, for instance, may indeed depend on the existence of intermolecular forces, but it is to be discussed and experimented on in terms of its own concepts rather than, say, that of the Van der Waals equation. So, too, the B Minor Mass is a "mere" assembly of diatonic tones - yet we have to understand and discuss it in musical, not acoustic language. If, still on the threshold of knowledge, we can already see that in the primary chemical elements there lies the potential for the synthesis of proteins and enzymes, and cell replication, cell-constituent assembly, speciation, learning and association, what may there not be still to be revealed?

Like other intermediate positions, it may not satisfy. Does it leave, for the Christian, room enough for a God with a loving personal relation to his creation? Does it provide, for the reductionist, too much room for self-deceiving religious aspirations to creep in? Perhaps it is not so much the possible existence and human awareness of some higher being that can most worry a scientist, but the idea of that being interfering with the natural course of events, with "natural law". Yet the question is not much different from the age-old one of whether our own day-today decisions (seemingly "free") actually modify events or not. If our belief in the one influence is valid and compatible with natural law, why not the other?

Dr Peacocke, though unequivocally Christian, is not, I think, pressing his views. His posture is like that of Bishop Butler in the Analogy of Religion, published almost exactly 250 years ago:

It is come, I know not how, to be taken for granted, by many Persons, that Christianity is not so much as a Subject of Enquiry; but that it is, now at length, discovered to be fictitious. And accordingly they treat it, as if, in the present Age, this were an agreed Point, among all People of Discernment; and nothing remained, but to set it up as a principal Subject of Mirth and Ridicule, as it were, by way of Reprisals, for having so long interrupted the Pleasures of the World. On the contrary, thus much, at least, will be here found, not taken for granted, but proved, that any reasonable Man, who will thoroughly consider the Matter, may be as much assured, as he is of his own Being, that, however, it is not so clear a Case, that there is nothing in it.

For those who do not like to see people bludgeoned into belief, and who are also interested in the work of recent years by both a theologian and a scientist, $\mathrm{Dr}$ Peacocke's eirenic writing will be much welcomed.

Sir William Paton, 13 Staverton Road, Oxford $\mathrm{OX} 26 \mathrm{XH}, \mathrm{UK}$, is Emeritus Professor of Pharmacology at the University of Oxford.

\section{New in paperback}

- The Birth of Particle Physics edited by Laurie M. Brown and Lillian Hoddeson (reviewed in Nature 308, 383; 1984). Publisher is Cambridge University Press, price is $£ 12.95, \$ 18.95$.

- The Ecological Web: More on the Distribution and Abundance of Animals by H.G. Andrewartha and L.C. Birch (reviewed in Nature 315, 81; 1985). Publisher is University of Chicago Press, price is $\$ 19.95, £ 16.95$.

- Measuring the Universe: Cosmic Dimensions from Aristarchus to Halley by Albert Van Helden (reviewed in Nature 316, 492; 1985). Publisher is University of Chicago Press, price is $\$ 8.95, £ 7.50$. 